\title{
ALLAMANDA CATHARTICA LINN.: EXTRACTION AND PHARMACEUTICAL EVALUATION OF VARIOUS EXTRACTS OF LEAVES AND FLOWERS
}

\author{
MEENAKSHI FARTYAL \\ Laboratory of Plant Tissue Culture and Secondary Metabolites, Department of Botany, University of Rajasthan, Jaipur, India \\ Email: mksh35@gmail.com
}

Received: 22 Jul 2016, Revised and Accepted: 20 Aug 2016

\begin{abstract}
Objective: Extraction and evaluation of the antifungal activity of extracts from leaves and flowers of Allamanda cathartica (Apocynaceae) Linn.

Methods: Leaves and flowers of $A$. cathartica were collected, dried and extracted by using well-established methods for alkaloids, flavonoids, steroids and crude extracts in polar and non-polar solvents. Extracts were screened for antifungal activity using 'Disc Diffusion Assay' against Candida albicans (Yeast), Aspergillus flavus and Tricophyton mentagrophyte (fungi). Inhibition zone (IZ), Activity index (AI), Minimum inhibitory concentration (MIC), Minimum fungicidal concentration (MFC) and Total activity (TA) were studied. Mean and standard deviation has also been calculated.

Results: $C$. albicans found to be the most susceptible organism while $T$. mentagrophyte found to be resistant. Alkaloid of leaf (IZ= 22 mm, AI= $0.65 \pm 0.02, \mathrm{MFC}=0.156 \mathrm{mg} / \mathrm{ml}, \mathrm{MIC}=0.078 \mathrm{mg} / \mathrm{ml}, \mathrm{TA}=557.59 \mathrm{ml} / \mathrm{g})$ showed the best activity against $C$. albicans. Pet ether extract $(\mathrm{IZ}=12 \mathrm{~mm}, \mathrm{AI}=$ $0.40 \pm 0.02, \mathrm{MFC}=0.312 \mathrm{mg} / \mathrm{ml}, \mathrm{MIC}=0.156 \mathrm{mg} / \mathrm{ml}, \mathrm{TA}=114.48 \mathrm{ml} / \mathrm{g})$ and water extract $(\mathrm{IZ}=13 \mathrm{~mm}, \mathrm{AI}=0.43 \pm 0.02, \mathrm{MIC}=0.312 \mathrm{mg} / \mathrm{ml}, \mathrm{MIC}=0.156$ $\mathrm{mg} / \mathrm{ml}, \mathrm{TA}=99.36 \mathrm{ml} / \mathrm{g}$ ) of flower also showed very good activities against $C$. albicans. The range of MFC and MIC found to be $1.25-0.156 \mathrm{mg} / \mathrm{ml}$ and $0.625-0.078 \mathrm{mg} / \mathrm{ml}$, respectively.
\end{abstract}

Conclusion: Results indicate the good antifungal potency of extracts against tested microorganisms. Hence, may be explored for the formation of new antifungal drugs.

Keywords: Antifungal activity, Alkaloid, Flavonoid, Steroid, Polar and non-polar solvents, Disc diffusion assay, Minimum inhibitory concentration, Minimum fungicidal concentration, Total activity

(C) 2016 The Authors. Published by Innovare Academic Sciences Pvt Ltd. This is an open access article under the CC BY license (http://creativecommons.org/licenses/by/4.0/) DOI: http://dx.doi.org/10.22159/ijcpr.2016v8i4.15272

\section{INTRODUCTION}

The use of medicinal plants as a source for relief from illness can be traced back over five millennia to written documents of the early civilization in China, India and the Near east, but it is doubtless an art as old as mankind. Neanderthals living 60,000 y ago in present day Iraq used plants such as hollyhock. These plants are still widely used in ethnomedicine around the world $[1,2]$. Medicinal plants still are a rich source of antimicrobial compounds. There has been an increasing interest worldwide on therapeutic values of natural products. It is believed that the cure, to any debilitating human ailments, may be found, among the world's flora in nature's pharmacy [3]. Phytochemicals have made a significant contribution in maintaining human health. The significance of drugs derived from plants cannot be over emphasized with the recent trend of high percentage of resistance in microorganisms to the present day antibiotics [4]. The effort has been intensified by researcher towards a search for more plant source of antimicrobial agents. In the present study Allamanda cathartica has been selected for the study.

Allamanda cathartica (common name Golden trumpet) is a woody climbing evergreen shrub belongs to family Apocynaceae. It is native to Central America and Brazil, cultivated in India for showy flowers, found wild in Karnataka. Various medicinal properties as a good purgative, Antidote for poisoning, inflammation, constipation and ascites are attributed to this plant. Distilled extract of the plant claims to the cure of malignancy, fungal and bacterial diseases, for colic and acute abdominal pain. It is used for jaundice and enlarged spleen resulting from malaria. It is active in vivo in mice and in vitro against human carcinoma of the nasopharynx. The alcoholic and aqueous extract is hypertensive. It's cathartic (milky sap) possess antibacterial and possibly anticancer activity. The present investigation was undertaken to find out the antifungal potential of extracts of different parts of $A$. cathartica against some fungi.

Alkaloids are known to have pharmacological effects and are used in medications, as recreational drugs or in entheogenic rituals.
Literature indicates that plant alkaloids have considerable biological activity [5, 6]. The presence of Alkaloids, Sterols, and Flavonoids in leaf of $A$. cathartica and their antifungal activity against Candida albicans were reported [7].

Flavonoids are potent water-soluble antioxidants and free radical scavengers, which prevent oxidative cell damage and have strong anti-cancer activity [8]. It was reported that flavonoids can improve the blood circulation and lower the blood pressure [9]. Different phytoconstituents such as alkaloids, phenolic compounds, flavonoids, saponins, glycosides, terpenoids, steroids, coumarins, quinones, phytosterols, proteins, and carbohydrates were identified in the aqueous, acetone, petroleum ether, chloroform and ethanol extracts of the flowers Allamanda cathartica Linn. [10].

Steroids are frequently used as signaling molecules, represents highly concentrated energy stores, along with phospholipids function as components of cell membranes. Literature related to the antimicrobial activity of steroids of Allamanda cathartica was not yet found.

The methanolic extracts of $A$. cathartica showed active inhibition against Salmonella typhi, salmonella paratyphi, Streptococcus aureus, Klebsiella vulgaris, Shigella dysenteriae, Shigella boydii and Escherichia [11]. Petroleum ether extract of $A$. cathartica showed good inhibition against Staphylococcus aureus (20 mm), Escherichia coli $(13 \mathrm{~mm})$, Pseudomonas aeruginosa $(19 \mathrm{~mm})$, Acinetobacter $\mathrm{sp}$ (20 $\mathrm{mm})$, Proteus sp (18 $\mathrm{mm})$ [12]. Allamanda cathartica (leaf) extract found to exhibit potential antimicrobial properties against human pathogenic bacteria Escherichia coli, Klebsiella pneumoniae, Pseudomonas aeruginosa and Proteus mirabilis [13]. Petroleum ether and chloroform extracts of Allamanda cathartica exhibited promising antifungal activity [14].

Considering the rich diversity of plants, it is expected that screening and scientific evaluation of plant extracts for their antimicrobial activity may provide new antimicrobial substances. Review of the current literature reveals that no work has been carried out for 
extraction and screening of specific compound from selected plant. Hence, in the present work an extraction and screening for antifungal activity of extracts of $A$. cathartica has been undertaken.

\section{MATERIALS AND METHODS}

Different parts of $A$. cathartica (leaf and flower) were collected in the month of April to June from the western parts of India (Jaipur, Rajasthan). Plants were identified by senior taxonomist at Department of Botany, University of Rajasthan and voucher specimen no: RUBL 21177 was submitted to the Herbarium, Botany Department, University of Rajasthan.

\section{Preparation of extracts}

\section{Alkaloids extraction}

Alkaloids were extracted from different parts of the selected plant by well-established method [15]. Finely powdered sample (100g) of plant parts were extracted in $20 \mathrm{ml}$ methanol after shaking of 15 minutes After filtration; filtrate kept for drying then residual mass were treated with $1 \% \mathrm{H}_{2} \mathrm{SO}_{4}(5 \mathrm{ml}$., 2 times). Extraction was then done in $10 \mathrm{ml}$. Chloroform $\left(\mathrm{CHCl}_{3}\right)$ by using a separating funnel. The organic layer of chloroform was rejected, and the aqueous layer was basified with $30 \%$ $\mathrm{NH}_{4} \mathrm{OH}\left(\mathrm{PH}^{\mathrm{H}}=9-10\right)$. Now again, extraction was done in $10 \mathrm{ml}$. chloroform and the organic layer of chloroform (lower layer) were collected in a flask, and repetition of the step was done with fresh chloroform. Extracts were then dried in vaccuo for further use.

\section{Flavonoid extraction}

Selected plant parts were separately washed with sterilized water; shade-dried, and finely powdered using a blender. Each sample was subjected to extraction, following the method of Subramanian and Nagarjan [16]. One hundred grams of each finely powdered sample was soxhlet extracted with $80 \%$ hot methanol $(500 \mathrm{ml})$ on a water bath for $24 \mathrm{~h}$ and filtered. The filtrate was re-extracted successively with petroleum ether (fraction I), diethyl ether (fraction II), and ethyl acetate (fraction III) using a separating funnel. Petroleum ether fractions were discarded as being rich in fatty substances, whereas diethyl ether and ethyl acetate fractions were analyzed for free and bound flavonoids respectively. The ethyl acetate fraction of each of the samples was hydrolyzed by refluxing with $7 \% \mathrm{H}_{2} \mathrm{SO}_{4}$ for $2 \mathrm{~h}$ (for removal of bound sugars) and the filtrate was extracted with ethyl acetate in separating funnel. Ethyl acetate extract obtained was washed with distilled water to neutrality. Diethyl ether (free flavonoids) and ethyl acetate fractions (bound flavonoids) were dried in vaccuo and weighed. The extracts were stored at $4{ }^{\circ} \mathrm{C}$ and were re-suspended in their respective solvents to get $10 \mathrm{mg} / \mathrm{ml}$ concentration for antimicrobial assay.

\section{Steroid extraction}

Steroids were extracted from different parts of the selected plant by well-established method [17] after preliminary detection of steroids. Finely powdered sample $(100 \mathrm{~g})$ of plant parts were extracted in petroleum ether for $2-4 \mathrm{hr}$. After filtration, the residual mass was treated with $15 \%$ ethanolic $\mathrm{HCl}$ for $4 \mathrm{hr}$. Extraction was then done in ethyl acetate followed by washing in dis. water to neutralize the extract. The neutral extract was then passed over sodium sulfate to remove moisture contents and was dried in vaccuo. Chloroform was used for reconstitution of extract, filtered and dried for further use.

\section{Extraction in polar and non-polar solvents}

Powder of all the two plant parts (Leaf and flower) were taken in different round bottom flasks in different solvents. $20 \mathrm{~g}$ powder was taken in each flask and water, methanol and petroleum ether were used as a solvent. Dried material and solvents were taken in 1:10 ratio. Those were kept at soxhlet unit for $24 \mathrm{~h}$. Then extracts were filtered. The filtrates were subjected to evaporation to obtain dried extract. The percentage yield of each dried plant extract was calculated.

\section{Selected test microorganisms}

Three pathogenic bacteria were screened, Candida albicans (MTCC no. 183), Aspergillus flavus (MTCC no. 277) and Tricophyton mentagrophyte (MTCC no. 7687). The pathogens were procured from IMTECH (Chandigarh, Punjab, India). Fungal strains were grown and maintained on Sabouraud Dextrose Agar medium.
Candida albicans is a major model of pathogenic yeast which is found in mouth, throat, intestine and genitourinary tract of human and considered as a common constituent of bowel flora together with many bacterial species e. g. E. coli, S. aureus and P. mirabilis. It lives in $80 \%$ of the human population with no harmful effects, although overgrowth results in candidiasis which is often observed in immune-compromised individuals such as patients of cancer, transplant, and AIDS. It is a causal agent of opportunistic oral and genital infections in humans [18]. Superficial and mycosis infections cause local inflammation and discomfort in human beings [19]. Candidiasis also known as 'thrush', which usually occurs in immune compromised people [20].

Aspergillus flavus is the second leading cause of invasive and non-invasive aspergillosis [21]. The presence of Aspergillus in the air is a major risk factor for both invasive and allergic aspergillosis [22]. A. flavus can cause storage problems in stored grains. It also causes diseases in economically important crops, such as maize and peanuts and produces potent mycotoxins. It can also be a human pathogen, associated with aspergillosis of the lungs and sometimes causing corneal, otomycotic and nasoorbital infections.

Tricophyton mentagrophyte is a cosmopolitan dermatophyte, belonging to a homogeneous group of fungi called the dermatophytes. The organism is found in soil, the floor of swimming pools, hairs of wild boar, cats and dogs, farm animals, foot wears and from human toe webs without clinical lesions. It requires keratin for growth and can cause a variety of cutaneous (hair, nail and skin) infections in humans and animals hence considered to be anthropophilic or zoophilic in nature $[23,24]$. It causes dermatophytosis in dogs, cats, cattle and especially in rodents [25-27].

\section{Antimicrobial assay}

Disc Diffusion Assay' was performed for screening [28]. SD agar base plates were seeded with the fungal inoculum (inoculum size $1 \times 10^{7} \mathrm{CFU} / \mathrm{ml}$ ). Sterile filter paper discs of Whatman no.1 $(6 \mathrm{~mm}$ in diameter) were impregnated with $100 \mu \mathrm{l}$ of each of the extract of concentration $10 \mathrm{mg} / \mathrm{ml}$ to give a final concentration of $1 \mathrm{mg} /$ disc. Discs were left to dry in vaccuo so as to remove residual solvent, which might interfere with the determination. Discs with extract were then placed on the corresponding seeded agar plates. Each extract was tested in triplicate along with Ketoconazole $(1 \mathrm{mg} / \mathrm{disc})$ for T. mentagrophyte and Terbinafine for $C$. albicans and A. flavus as standard drugs. The plates were kept at $4{ }^{\circ} \mathrm{C}$ for diffusion of extract, thereafter were incubated at $27^{\circ} \mathrm{C}($ C. albicans and A. flavus for $48 \mathrm{~h}$ and T. mentagrophyte for 5-7 d). Activity index for each extract was calculated [table 1] by the standard formula viz.

$$
\begin{gathered}
\text { Activity index }=\text { IZ produced by the extract } / \mathrm{IZ} \text { produced by } \\
\text { standard }(\mathrm{IZ}=\text { inhibition zone })
\end{gathered}
$$

\section{Determination of minimum inhibitory concentration (MIC) and minimum fungicidal (MFC) concentration}

Minimum inhibitory concentration (MIC) was determined for each plant extract showing antimicrobial activity against the test pathogens. 'Broth microdilution' method was followed for determination of MIC values [29]. Plant extracts were resuspended in acetone (which has no activity against test microorganisms) to make $10 \mathrm{mg} / \mathrm{ml}$ final concentration. Two-fold serially diluted extracts were added to broth media of 96-wells of microtiter plates.

Thereafter $100 \mu \mathrm{l}$ inoculums $\left(1 \times 10^{7} \mathrm{CFU} / \mathrm{ml}\right)$ was added to each well. Fungal suspensions were used as negative control, while broth containing standard drug was used as positive control. Microtiter plates were then incubated at $27^{\circ} \mathrm{C}$ for $48 \mathrm{~h}$. Each extract was assayed in duplicate and each time two sets of microplates were prepared, one was kept for incubation while another was kept at $4{ }^{\circ} \mathrm{C}$ for comparing the turbidity in the wells of a microplate. The MIC values were taken as the lowest concentration of the extracts in the well of the microtiter plate that showed no turbidity after incubation. The turbidity of the wells in the microtiter plate was interpreted as the visible growth of microorganisms. The minimum fungicidal concentration (MFC) was determined by subculturing $50 \mu \mathrm{l}$ from each well showing no apparent growth [table 2]. Least concentration of extract showing no visible growth on subculturing was taken as MFC. 
Table 1: Antifungal activity of extracts of Allamanda cathartica against some pathogenic fungi

\begin{tabular}{|c|c|c|c|c|c|c|c|}
\hline \multirow[t]{3}{*}{ Plant part } & \multirow[t]{3}{*}{ Extract } & \multicolumn{6}{|c|}{ Microorganisms } \\
\hline & & \multicolumn{2}{|c|}{ C. albicans } & \multicolumn{2}{|l|}{ A. flavus } & \multicolumn{2}{|c|}{ T. mentagrophyte } \\
\hline & & IZ(mm) & AI & $\mathrm{IZ}(\mathrm{mm})$ & AI & $\mathrm{IZ}(\mathrm{mm})$ & $\mathbf{A I}$ \\
\hline \multirow[t]{7}{*}{ Leaf } & A1 & 22 & $0.65 \pm 0.01$ & - & - & - & - \\
\hline & S1 & 7 & $0.20 \pm 0.01$ & - & - & - & - \\
\hline & E1 & - & - & 7 & $0.23 \pm 0.01$ & - & - \\
\hline & E2 & 9 & $0.26 \pm 0.01$ & - & - & - & - \\
\hline & P1 & - & - & - & - & - & - \\
\hline & M1 & - & - & - & - & - & - \\
\hline & W1 & - & - & - & - & - & - \\
\hline \multirow[t]{7}{*}{ Flower } & $\mathrm{A} 2$ & 8 & $0.27 \pm 0.01$ & - & - & - & - \\
\hline & S2 & 9 & $0.30 \pm 0.01$ & - & - & - & - \\
\hline & E1 & - & - & 7 & $0.23 \pm 0.01$ & - & - \\
\hline & E2 & - & - & 7 & $0.23 \pm 0.01$ & - & - \\
\hline & P2 & 12 & $0.40 \pm 0.01$ & - & - & - & - \\
\hline & M2 & 9 & $0.30 \pm 0.01$ & - & - & - & - \\
\hline & W2 & 13 & $0.43 \pm 0.02$ & - & - & - & - \\
\hline
\end{tabular}

(a) A1, A2= Alkaloid extract of respective plant parts, (b) S1, S2= Steroid extract of respective plant parts, (c) E1, E2= Free and Bound flavonoids of respective plant parts, (d) P1, P2 = Pet ether extract of respective plant parts, (e) M1, M2= Methanolic extract of respective plant parts, (f) W1, W2= Water extract of respective plant parts, (g) IZ=Inhibition zone in mm (value: including $6 \mathrm{~mm}$ diameter of disc), (h) AI= Activity index (IZ developed by extract/IZ developed by standard), (i) [-]= no activity, (j) $\pm=$ SEM

Table 2: MIC and MFC of active extracts of Allamanda cathartica against some pathogenic fungi

\begin{tabular}{|c|c|c|c|c|c|c|c|c|c|c|c|c|c|c|c|}
\hline \multicolumn{9}{|c|}{ Plant parts and Extracts Leaf } & \multicolumn{7}{|c|}{ Flower } \\
\hline Microorganisms & $\begin{array}{l}\text { MIC and } \\
\text { MFC }\end{array}$ & $\mathbf{A 1}$ & S1 & E1 & E2 & P1 & M1 & $\mathbf{W 1}$ & A2 & S2 & E1 & $\mathbf{E 2}$ & P2 & M2 & $\mathbf{W} 2$ \\
\hline \multirow[t]{2}{*}{ C. albicans } & MFC & 0.156 & 1.25 & - & 0.625 & - & - & - & 1.25 & 0.625 & - & - & 0.312 & 0.625 & 0.312 \\
\hline & MIC & 0.078 & 0.625 & - & 0.312 & - & - & - & 0.625 & 0.312 & - & - & 0.156 & 0.312 & 0.156 \\
\hline \multirow[t]{2}{*}{ A. flavus } & MFC & - & - & 1.25 & - & - & - & - & - & - & 1.25 & 1.25 & - & - & - \\
\hline & MIC & - & - & 0.625 & - & - & - & - & - & - & 0.625 & 0.625 & - & - & - \\
\hline \multirow[t]{2}{*}{ T. mentagrophyte } & MFC & - & - & - & - & - & - & - & - & - & - & - & - & - & - \\
\hline & MIC & - & - & - & - & -- & - & - & - & - & - & - & - & - & - \\
\hline
\end{tabular}

(a) A1, A2= Alkaloid extract of respective plant parts, (b) S1, S2= Steroid extract of respective plant parts, (c) E1, E2= Free and Bound flavonoids of respective plant parts, (d) P1, P2 = Pet ether extract of respective plant parts,(e) M1, M2= Methanolic extract of respective plant parts, (f) W1, W2= Water extract of respective plant parts, (g) MIC= Minimum inhibitory concentration, (h) MFC=Minimum fungicidal concentration, (i) [-] = no activity.

\section{Total activity (TA) determination}

Total activity is the volume up to which test extract can be diluted without losing the ability to kill microorganisms.
It is calculated by dividing the amount of extract from $1 \mathrm{~g}$ plant material by the MIC of the same extract or compound isolated and is expressed in $\mathrm{ml} / \mathrm{g}$ [30] [table 3].

Table 3: Quantity and total activity of crude extracts of Allamanda cathartica Linn

\begin{tabular}{|c|c|c|c|c|c|}
\hline \multirow[t]{2}{*}{ Plant part } & \multirow[t]{2}{*}{ Extract } & \multirow[t]{2}{*}{ Quantity of extract mg/g dwt } & \multicolumn{3}{|c|}{ Total Activity(ml/g) } \\
\hline & & & C. albicans & A. flavus & T. mentagrophyte \\
\hline \multirow[t]{7}{*}{ Leaf } & A1 & 43.5 & 557.69 & - & - \\
\hline & S1 & 281.67 & 450.67 & - & - \\
\hline & E1 & 61.1 & - & 98.56 & - \\
\hline & E2 & 124.70 & 399.68 & - & - \\
\hline & P1 & 35 & - & - & - \\
\hline & M1 & 203.75 & - & - & - \\
\hline & W1 & 112.5 & - & - & - \\
\hline \multirow[t]{7}{*}{ Flower } & A2 & 674.12 & 1078.59 & - & - \\
\hline & S2 & 450 & 1442.30 & - & - \\
\hline & E1 & 175 & - & 280 & - \\
\hline & E2 & 348.34 & - & 557.34 & - \\
\hline & P2 & 17.86 & 114.48 & - & - \\
\hline & M2 & 172.23 & 552.01 & - & - \\
\hline & W2 & 15.5 & 99.36 & - & - \\
\hline
\end{tabular}

(a) A1, A2= Alkaloid extract of respective plant parts, (b) S1, S2= Steroid extract of respective plant parts, (c) E1, E2= Free and Bound flavonoids of respective plant parts, (d) P1, P2 = Pet ether extract of respective plant parts, (e) M1, M2= Methanolic extract of respective plant parts, (f) W1, W2= Water extract of respective plant parts, $(\mathrm{g}) \mathrm{TA}=$ total activity (extract per gm dried plant part/MIC of extract)

\section{RESULTS}

Antimicrobial efficacy of secondary metabolites (Alkaloid, steroid and flavonoid) and crude extracts in polar and non polar solvents (methanol, pet ether, water) were assessed by using IZ, AI (table 1), MIC, MFC (table 2). Quantity of extract per gram of plant material was also calculated (table 3 ). In present investigation, 14 extracts were tested against three pathogenic organisms, including one yeast 
C. albicans and two fungi A. flavusand T. mentagrophyte. Among all the tested extracts all the three crude extracts of leaf found to be inactive against all the tested pathogens. T. mentagrophyte found to be resistant pathogen as no extract showed activity against it. $C$. albicans found to be most susceptible organism as 8 out of 14 extracts showed activity against it. Best activity was observed in alkaloid extract of leaf $(\mathrm{IZ}=22 \mathrm{~mm}, \mathrm{AI}=0.65 \pm 0.02, \mathrm{MFC}=0.156 \mathrm{mg} / \mathrm{ml}$, MIC $=0.078 \mathrm{mg} / \mathrm{ml}, \mathrm{TA}=557.59 \mathrm{ml} / \mathrm{g}$ ) against $C$. albicans. Pet ether extract of flower $(\mathrm{IZ}=12 \mathrm{~mm}, \mathrm{AI}=0.40 \pm 0.02, \mathrm{MFC}=0.312 \mathrm{mg} / \mathrm{ml}, \mathrm{MIC}=$ $0.156 \mathrm{mg} / \mathrm{ml}, \mathrm{TA}=114.48 \mathrm{ml} / \mathrm{g}$ ) and water extract of flower $(\mathrm{IZ}=13$ $\mathrm{mm}, \mathrm{AI}=0.43 \pm 0.02, \mathrm{MFC}=0.312 \mathrm{mg} / \mathrm{ml}, \mathrm{MIC}=0.156 \mathrm{mg} / \mathrm{ml}, \mathrm{TA}=99.36$ $\mathrm{ml} / \mathrm{g}$ ) also showed very good activities against C. albicans. Bound flavonoid of leaf $(\mathrm{IZ}=9 \mathrm{~mm}, \mathrm{AI}=0.26 \pm 0.01, \mathrm{MFC}=0.625 \mathrm{mg} / \mathrm{ml}, \mathrm{MIC}=$ $0.312 \mathrm{mg} / \mathrm{ml}, \mathrm{TA}=399.68 \mathrm{ml} / \mathrm{g}$ ), steroid of flower $(\mathrm{IZ}=9 \mathrm{~mm}, \mathrm{AI}=$ $0.30 \pm 0.01, \mathrm{MFC}=0.625 \mathrm{mg} / \mathrm{ml}, \mathrm{MIC}=0.312 \mathrm{mg} / \mathrm{ml}, \mathrm{TA}=1442.30 \mathrm{ml} / \mathrm{g}$ ), alkaloid of flower $(\mathrm{IZ}=8 \mathrm{~mm}, \mathrm{AI}=0.27 \pm 0.01, \mathrm{MFC}=1.25 \mathrm{mg} / \mathrm{ml}, \mathrm{MIC}=$ $0.625 \mathrm{mg} / \mathrm{ml}, \mathrm{TA}=1078.9 \mathrm{ml} / \mathrm{g}$ ) and methanolic extract of flower (IZ= $9 \mathrm{~mm}, \mathrm{AI}=0.30 \pm 0.01, \mathrm{MFC}=0.625 \mathrm{mg} / \mathrm{ml}, \mathrm{MIC}=0.312 \mathrm{mg} / \mathrm{ml}, \mathrm{TA}=$ $552.01 \mathrm{ml} / \mathrm{g}$ ) showed good activities against $C$. albicans while free flavonoid of leaf $(\mathrm{IZ}=7 \mathrm{~mm}, \mathrm{AI}=0.23 \pm 0.01, \mathrm{MFC}=1.25 \mathrm{mg} / \mathrm{ml}, \mathrm{MIC}=$ $0.625 \mathrm{mg} / \mathrm{ml}, \mathrm{TA}=98.56 \mathrm{ml} / \mathrm{g})$, free flavonoid of flower $(\mathrm{IZ}=7 \mathrm{~mm}, \mathrm{AI}=$ $0.23 \pm 0.01, \mathrm{MFC}=1.25 \mathrm{mg} / \mathrm{ml}, \mathrm{MIC}=0.625 \mathrm{mg} / \mathrm{ml}, \mathrm{TA}=280 \mathrm{ml} / \mathrm{g}$ ) and bound flavonoid of flower $(\mathrm{IZ}=7 \mathrm{~mm}, \mathrm{AI}=0.23 \pm 0.01, \mathrm{MFC}=1.25$ $\mathrm{mg} / \mathrm{ml}, \mathrm{MIC}=0.625 \mathrm{mg} / \mathrm{ml}, \mathrm{TA}=557.34 \mathrm{ml} / \mathrm{g}$ ) showed satisfactory activities against $A$. flavus. Steroid of leaf (IZ $=7 \mathrm{~mm}, \mathrm{AI}=0.20 \pm 0.01$, $\mathrm{MFC}=1.25 \mathrm{mg} / \mathrm{ml}, \mathrm{MIC}=0.625 \mathrm{mg} / \mathrm{ml}, \mathrm{TA}=450.67 \mathrm{ml} / \mathrm{g}$ ) showed satisfactory activity against $C$. albicans.

Among all the tested extracts, none of the tested extracts showed activity against more than one pathogen. Plant extracts, which had shown activity in diffusion assay, were evaluated for their MIC and MFC values (table 2). The range of MFC and MIC of extracts recorded was $1.25-0.156$ and $0.625-0.078$, respectively. In present study, lowest MIC value $0.078 \mathrm{mg} / \mathrm{ml}$ was recorded against $C$. albicans, indicating significant antimicrobial efficacy of tested extracts. Quantity of extract obtained per gram from plant parts and TA was calculated and recorded (table 3). TA indicates the volume at which extract can be diluted without losing ability to kill microorganisms. High values of TA were observed against $C$. albicans $(1078.59 \mathrm{ml} / \mathrm{g})$ followed by A. flavus (557.34 ml/g).

\section{DISCUSSION}

Extracts from different parts of $A$. cathartica have previously been studied for their antifungal activity but, still, meager work has been carried out as far as the antifungal activity of steroids and crude extracts is concerned. Most of the research has been restricted on the determination of IZ of extracts without calculating AI, MIC, MFC and TA. Determination of MIC and MFC has now become an inevitable step in antimicrobial studies in order to establish their antimicrobial activity so as to explore them at industrial level for the production of drugs, which could replace the existing ones. Hence, most of the studies carried out so far could only reveal their antimicrobial activities, but are not helpful for establishing them as antifungal. The result of the present study indicated that the extracts of both the parts (leaf and flower) of A. cathartica have antifungal activity against two of the selected fungus. The results were in agreement with the findings of previous studies. Furthermore, it may help to discover new chemical classes of antifungal that could serve as selective agents for the maintenance of human health and provide biochemical tools for the study of infectious diseases.

\section{CONCLUSION}

C. albicans found to be most susceptible organism while T. mentagrophyte found to be resistant throughout the study. Best activity was observed in the alkaloid extract of the leaf against $C$. albicans. Pet ether and water extract of the flower were also showed a good level of antifungal activities while other extracts found to have marginal activities. Therefore, extracts of $A$. cathartica will be very beneficial in the studies relevant to the formation of nature based antifungal preparations.

\section{ACKNOWLEDGEMENT}

The author is thankful to 'Head' Department of Botany, the University of Rajasthan for providing all necessary facilities and
Prof. Padma kumar for her assistance in language and proofreading of the manuscript.

\section{CONFLICT OF INTERESTS}

Declare none

\section{REFERENCES}

1. Stockwell C. Nature's pharmacy. London: Century Hutchinson Ltd; 1988.

2. Thomson WA. editor. Medicines from the Earth. Maidenhead: McGraw-Hill Book Co.; 1978.

3. Olowosulu AK, Ibrahim YK. Studies on the antimicrobial screening of aqueous extracts of five plants used in Folk medicine in Nigeria, West Africa. J Biol Sci 2006;3:21-6.

4. Ibekwe VI, Ubochi KC, Anyanwu BN. Prevalence of penicillia resistance in organisms that cause sexually transmitted diseases in Port Harcourt, Nigeria. Int J Environ Health Res 2000;10:251-5.

5. Cowan MM. Plant products as antimicrobial agents. Clin Microbiol Rev 1999;12:564-82.

6. Okunade AL, Elwin-Lewis MPF, Lewis WH. Natural antimycobacterial metabolites: current status. Phytochemistry 2000;65:1017-32.

7. Scio E, Mendes RF, Motta EVS, Bellozi PMQ. Antimicrobial and antioxidant activities of some plant extract. Phytochemicals as Nutraceuticals-Global Approaches to their Role in Nutrition and Health; 2012.

8. Del-Rio A, Obdulio BG, Castillo J, Marin RR, Ortuno A. Uses and properties of citrus flavonoids. J Agric Food Chem 1997;45:4505-15.

9. Blumenthal M. The $\mathrm{ABC}$ clinical guide to herbs. Austin: American botanical council; 2003. p. 239.

10. Joselin J, Sarasabai T, Brintha S, Florence AR. Screening of select ornamental flowers of the family Apocynaceae for phytochemical constituents. Asian Pac J Trop Dis 2012;2:260-4.

11. Britto AJD, Sebastian SR, Sujin RM. Phytochemical and antibacterial screening of seven Apocynaceae species against human pathogens. Int J Pharm Pharm Sci 2011;3:278-81.

12. Rajamanickam K, Sudha S. In vitro antimicrobial activity and in vivo toxicity of Moringa oleifera and Allamanda cathartica against multiple drug resistant clinical pathogens. Int J Pharma Bio Sci 2013;4:768-75.

13. Md Chowdhury AN, Ashrafuzzaman M, Md Ali H, Liza LN. Antimicrobial activity of some medicinal plants against multi-drug resistant human pathogens. Adv Biosci Bioeng 2013;1:1-24.

14. Singha IM, Unni BG, Kakoty Y, Das J. Evaluation of in vitro antifungal activity of medicinal plants against phytopathogenic fungi. Arch Phytopathol Plant Prot 2011;44:1033-40.

15. Ramawat KG, Merillon JM. Biotechnology: secondary metabolites. Science Pub Inc.; 2000.

16. Subramanian SS, Nagarjan S. Flavonoids of the seeds of Crotolaria retusa and Crotolaria striata. Curr Sci 1969;38:65.

17. Tomita Y, Uomori A, Minato H. Steroidal sapogenins and sterols in tissue cultures of Dioscorea tokora. Phytochemistry 1970;9:111-4.

18. Enfert C, Hube B. editors. Candida: comparative and functional genomics. Caister Academic Press; 2007.

19. Pappas PG. Invasive candidiasis. Infectious Disease Clinics North Am 2006;20:485-506.

20. Ryan KJ, Ray CG. Sherris medical microbiology. 4th ed. Mc Graw Hill; 2004.

21. Hedayati MT, Pasqualotto AC, Warn PA, Bowyer P. Aspergillus flavus: human pathogen, allergen and mycotoxin producer. Microbiology 2007;153:1677-92.

22. Denning DW, Venkateswarlu K, Oakley KL, Anderson MJ. Itraconazole resistance in Aspergillus fumigatus. Antimicrob Agents Chemother 1997;41:1364-8.

23. Sanchez-Castellanos ME, Mayrga-Rodrigues JA, Sandoval-Tress C, Hernandz-Torres M. Tinea incognito due to Tricophyton mentagrophyte. Mycoses 2007;50:85-7.

24. Van Rooij P, Detandt M, Nolard N. Tricophyton mentagrophyte of rabbit origin causing the family incidence of kerion: an environmental study. Mycoses 2006;49:426-30.

25. Ajello L, Cheng S. The perfect state of T. mentagrophyte. Sabouraudia 1967:5:230-4.

26. George LK, Roberts CS, Menges RW, Kalpan W. Tricophyton mentagrophyte infection on dogs and cats. J Am Vet Med Assoc 1957; 130:427-32. 
27. Houck HE, Cooley JE, Lowitt MH, Kao GF. Tinea caput medusa; an unusual presentation of Tricophyton mentagrophyte on the scalp. Cutis 1996;58:48-52.

28. Andrews JM. BSAC standardized disc susceptibility testing method. J Antimicrob Chemother 2001;4:43-57.

29. Basri DF, Fan SH. The potential of aqueous and acetone extracts of gall of Quercus infectoria as antibacterial agents. Indian J Pharmacol 2005;37:26-9.
30. Eloff JN. Quantifying the bioactivity of the plant extracts during screening and bioassay-guided fractionation. Phytomedicine 2004;11:370-1.

\section{How to cite this article}

- Meenakshi Fartyal. Allamanda cathartica linn.: Extraction and pharmaceutical evaluation of various extracts of leaves and flowers. Int J Curr Pharm Res 2016;8(4):28-32. 